\title{
Effects of Three Acaricides on the Germination Rate and Head Weight of Taşköprüi Garlic in Turkey
}

\author{
Sultan Çobanoğlu' ${ }^{1}$, Cihan Cilbircioğlu2 ${ }^{2}$, Atilla Hepkorucu ${ }^{3}$ \\ ${ }^{1}$ Plant Protection Department, Ankara University Agriculture, Ankara, Turkey \\ ${ }^{2}$ Organic Agricultural Department, Taşköprü Vocational High School, Kastamonu University, Kastamonu, Turkey \\ ${ }^{3}$ Banking and Insurance Department, Taşköprü Vocational High School, Kastamonu University, Kastamonu, \\ Turkey \\ Email: *cihancilbirci@hotmail.com, ahepkorucu@gmail.com
}

Received 31 December 2015; accepted 16 January 2016; published 20 January 2016

Copyright (C) 2016 by authors and OALib.

This work is licensed under the Creative Commons Attribution International License (CC BY).

http://creativecommons.org/licenses/by/4.0/

(c) (i) Open Access

\begin{abstract}
Three acaricides (azadirachtin, abamectin, and hexythiazox) were used, the effects on development parameters of Taşköprü garlic, Allium sativum L. (Asparagales: Amaryllidaceae) as seed treatment. This research was done in 2013-2014 on one hectare of garlic at Alatarla, Kastamonu, Turkey. Each acaricide and the untreated control were designated as four replicates on 16 plots. The effects of these acaricides on the germination rate and head weight of Taşköprü garlic were evaluated through regular sampling. Azadirachtin positively affected germination rate of Taşköprü garlic, while the other two acaracides had no effects on germination rate. None of the acaricides affected garlic head weights or head development. This is the first field study to evaluate acaracides that may also affect plant development.
\end{abstract}

\section{Keywords}

Allium sativum L., Neemazal, Abamectin, Hexythiazox, Germination Rate, Seed

Subject Areas: Agricultural Engineering, Agricultural Science

\section{Introduction}

Pesticides are chemical agents used to reduce the destructive effects of insects, rodents, weeds, fungi, and other pests that lower the value of a commodity during production, storage, or consumption. However, pesticides also have negative effects on environment. Intensive use of insecticides can cause environmental pollution, deteri-

${ }^{*}$ Corresponding author.

How to cite this paper: Çobanoğlu, S., Cilbircioğlu, C. and Hepkorucu, A. (2016) Effects of Three Acaricides on the Germination Rate and Head Weight of Taşköprü Garlic in Turkey. Open Access Library Journal, 3: e2276.

http://dx.doi.org/10.4236/oalib.1102276 
oration of untargeted species, and foster resistance problems [1]. Pesticides and their residues can accumulate on plants, enter the food chain, or cause chronic toxicities [2]. Pesticides may induce phytotoxic effects on leaves, lead to morphological, anatomical or physiological changes in plants, or inhibit pollen germination and pollen tube formation [3]. Pesticide can also cause acute or chronic poisoning in bees with serious economic losses [4].

Therefore, use of chemicals has been limited in recent years, and biological or cultural methods have been advocated [5]. Natural plant extracts with biological activities against diseases and insects are being investigated, and herbal insecticides have been found to be effective against several pests [6]. Other natural products such as plant extracts can help control weeds, plant diseases, and insects [7] [8].

Early research on herbal pesticides included evaluations of extracts of neem tree seeds, Azadirachta indica A. Juss (Meliaceae), which includes the active substance azadirachtin that is effective against insects. Neem products affect feeding, growth, and development stages of insects and mites. Pesticides (active ingradients) with slow modes of action are more important in integrated pest management systems than the rapid destructive effects of synthetic insecticides [9]-[12]. Neem pesticide products are registered in more than 40 countries, and they are used against key pests of fruits, vegetables, and flowers [10] [13].

Product from actinomycete bacteria (Actinobacteria), Streptomyces avermitilis (ex Burg) Kim \& Goodfellow (Actinomycetales: Streptomycetaceae), is found naturally in the soil. It is accepted by United States Environment Protection Agency (EPA) as second class toxic pesticide [14]. Hexythiazox is a mixture of four stereoisomers chemical compounds from the group of thiazolidines and carboxamides. Hexythiazox is an effective acaricide on mite eggs and nymphs, like juvenile stages but not adults. The precise mode of action of this acaracide is not known (1986 unpublished report by R. B. Chapman: Toxicity of nissorun to two-spotted spider mite. Entomol. Dept., Lincoln College, Canterbury, UK, 22 p.).

One of the most commonly produced vegetable crops in the world is garlic, Allium sativum L. (Asparagales: Amaryllidaceae). Garlic is used as a spice mash, a canned product, a dried powder, garlic oil, and garlic pellets. Because garlic has a wide range of uses and it has positive effects on human health, research on this plant has increased. Also, it can be grown in different environmental conditions and is economically important where it grows. According to United Nations Food and Agricultural Organization, 24.3 million metric tons of garlic was grown worldwide in 2013 [15]. Nearly 80\% of this global production was from China, while India, South Korea, Egypt, and Russia follow China as the top five countries in production of garlic [15]. Garlic is used in medicine for a wide range of symptoms such as asthma, hypertension, bronchitis, cancer, circulatory weaknesses, colds, colitis, and coughing [16].

Garlic also is an important crop in Turkey, where over 87,000 tons is produced annually; which accounted for $0.36 \%$ of the total world garlic production in 2013 [15]. The greatest production area in Turkey is in Taşköprü Province, especially near the city of Kastamonu (25.2\% of total production in Turkey). Taşköprü garlic is recognized as one of the best garlic varieties in Turkey and the rest of the world. In 2012, there was 18,500 ha of Taşköprü garlic with total production of 16,650 tons and yields of $900 \mathrm{~kg} / \mathrm{ha}$ [17]. In Taşköprü Province, 3500 families (about 40,000 people) are employed in garlic production. In Kastamonu, mainly Taşköprü garlic is grown, but there are 216 kinds of local garlic cultivars, including some Chinese varieties that are grown.

Although garlic is now grown in almost every region of the world, it grows well under temperate climates on sandy, loamy, and argilliferous soils, especially in soils rich in germanium and selenium [18]. Some of the highest quality garlic in the world is grown on the Taşköprü Plain where $85 \%$ of the soil has a permeable, loamyargillifereous structure that garlic needs. In addition, Taşköprü has an optimum climate for garlic production with a warm, humid spring [17]. Adequate rainfall is received in February and March when garlic germinates, and the crop can be grown without additional irrigation in Kastamonu [18]. Diseases and pests can cut garlic yields by $10 \%-50 \%$, and mites are one of the most important problems on onions, garlic, and bulbous ornamental plants [19]-[27]. In preparation for this study, garlic producers on the Taşköprü Plain were interviewed and asked to fill out questionnaires concerning the effects of diseases and pests on garlic yields. From these surveys, it was found that approximately 800 hectares of garlic in 15 villages was in risk of being lost because of pests, so these producers had to move to poorer lands at higher altitudes. Because of severe mite damage in this area, extensive spraying was done, which could lead to environmental degradation or resistance in the mite population. The purpose of this study was to determine the effects of three acaricides on garlic germination and production. 


\section{Materials and Methods}

This study was performed in 2013-2014 on a 0.2 hectare field located in Alatarla, Turkey. A local variety, Taşköprü garlic, was planted at $1250 \mathrm{~kg}$ per hectare in March into $3 \times 10$ meter plots. To prevent cross contamination for comparison acariside effects, each plot was separated by a three meters of empty space. The experiment was set up as a randomized complete block design with four treatments (three acaracides and an untreated control) each plot has four replicates. Thus, there was a total of 16 plots covering about one hectare and plots were randomly assigned. Before planting, garlic cloves were treated by dipping them in abamectin (Avirmec EC ${ }^{\circledR}$, Koruma, İzmit, Turkey) at $30 \mathrm{ml} / 100 \mathrm{~L}$ water, azadirachtin (NeemAzal-T/S ${ }^{\circledR}$, Verim Grup, İstanbul, Turkey) at $30 \mathrm{ml} / 100 \mathrm{~L}$ water, or hexythiazox (Yoksorrun $5 \mathrm{EC}^{\circledR}$, Agrobest Grup, Izmir, Turkey) at $50 \mathrm{ml} / 100$ L.water. Garlic cloves were immersed in one of the three acaricide-water treatments for 15 minutes before planting. The application of insecticides which is the advised and regulated by Ministry of Agriculture.

The numbers of germinating garlic plants were estimated by, in a $1 \mathrm{~m}^{2}$ area of each plot were counted three times and taken consideration by the average values during the germination period in April and May. To determine yields at harvest, six garlic heads from each plot were weighed. Data were analized with an ANOVA test.

\section{Results \& Discussion}

As a group, the acaricides significantly affected garlic germination $(P<0.001)$ (Table 1$)$. However, a significant positive effect on germination was only seen for azadirachtin (Table 2). Although germination rates were numerically higher than the control for abamectin, and hexythiazox, these differences were not statisically significant (Table 2, Figure 1). As a group and individually, the three acaricides did not significantly affect garlic development or head weights $(P<0.472)$ (Table $1 \&$ Table 2). The non significant effect on head weight is important, as growers require high average weights. However, the acaricides did contribute to greater variation in head weight than in the untreated control (Figure 2).

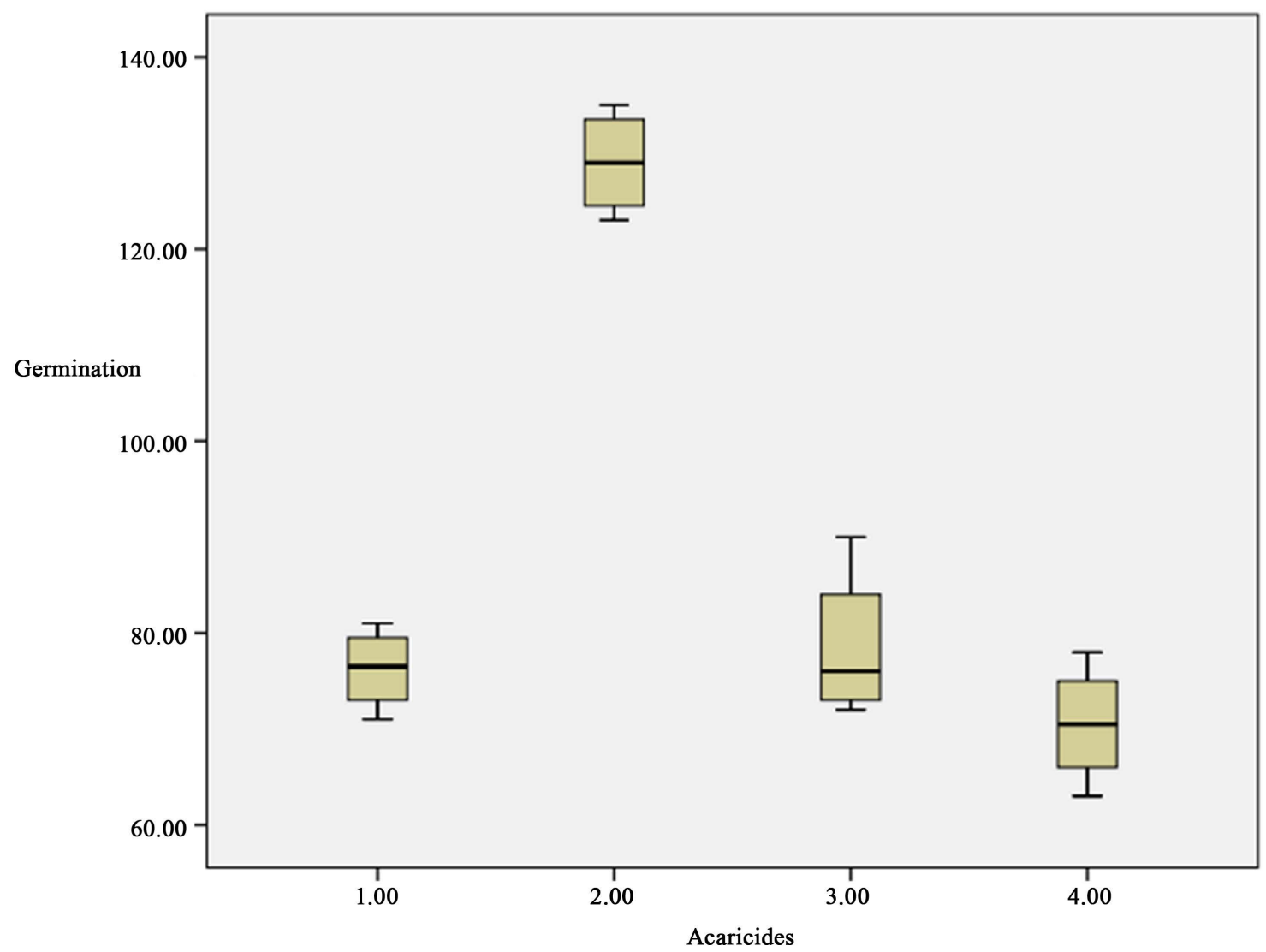

Figure 1. Box-Jenkins plot for germination rate with acaricides. 


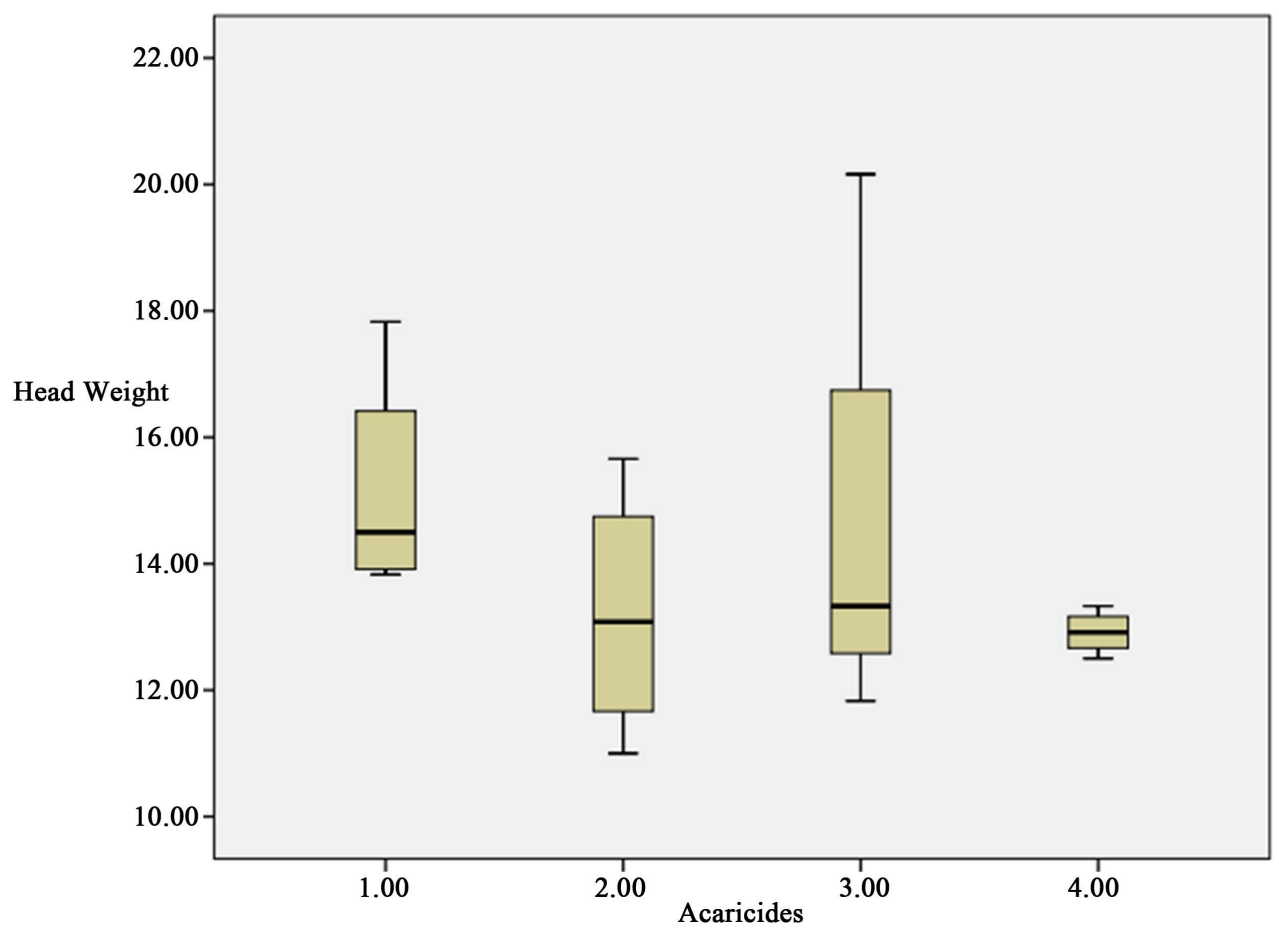

Figure 2. Box-Jenkins plot for head weights with acaricides.

Table 1. Analysis of variance (ANOVA) of the effects of acaricides on germination rates and head weights of Taşköprü garlic.

\begin{tabular}{ccccccc}
\hline Factor & Source of variation & Sums of squares & Degrees of freedom & Mean square & F & $P$ \\
\hline \multirow{3}{*}{ Germination } & Acaracide treatment & 8857.19 & 3 & 2952.34 & 77.57 & $>0.001$ \\
& Error & 456.75 & 12 & 38.06 & \\
& Total & 9313.94 & 15 & & \\
\multirow{2}{*}{ Head weight } & Acaracide treatment & 14.4219 & 3 & 5.81 & 0.90 & 0.472 \\
& Error & 64.47 & 12 & 5.37 & \\
\hline
\end{tabular}

Table 2. Effects of acaricides on germination rates and head weights of Taşköprü garlic in Alatarla.

\begin{tabular}{|c|c|c|c|c|c|}
\hline & & \multirow{2}{*}{ Mean } & \multirow{2}{*}{ Std. error } & \multicolumn{2}{|c|}{ 95\% confidence interval for mean } \\
\hline & & & & Lower bound & Upper bound \\
\hline \multirow{4}{*}{$\begin{array}{l}\text { Germination } \\
\left(\text { plants } / \mathrm{m}^{2} \text { ) }\right.\end{array}$} & Abamectin & 76.25 & 2.14 & 69.45 & 83.05 \\
\hline & Azadirachtin & 129.00 & 2.74 & 120.28 & 137.72 \\
\hline & Hexythiazox & 78.50 & 4.03 & 65.67 & 91.33 \\
\hline & Untreated control & 70.50 & 3.12 & 60.56 & 80.44 \\
\hline \multirow{4}{*}{ Head weight (g) } & Abamectin & 15.17 & 0.93 & 12.22 & 18.11 \\
\hline & Azadirachtin & 13.21 & 1.00 & 10.02 & 16.39 \\
\hline & Hexythiazox & 14.66 & 1.87 & 8.72 & 20.60 \\
\hline & Untreated control & 12.92 & 0.17 & 12.36 & 13.47 \\
\hline
\end{tabular}


This study showed that azadirachtin had the greatest effect on garlic germination. Neither abamectin or hexthiazox had any effects on garlic germination, and none of the acaracides had an impact on the head weights of Taşköprü garlic. This is the first study on the effects of acaricides on garlic germination. In future research, correlations between acaricide type and germination rate should be examined.

The results from garlic produced area proved that the pest management in production of organic vegetables can be successfully performed with the allowed preparations such as Melia azedarach L. on some pests [28]-[30]. There was no significant differences were found between natural (Neem Azal T/S), and conventional pesticides in respect to yield and fruit properties [31]. [32] were found as slightly harmful for the side effects of neem oil and NeemAzal on the predatory mite Phytoseiulus persimilis. These datas proofed our neem oil result, due to Neem Azal has not any side effects of the beneficials and sucessfully effective on the mites and germiation rate will be higher.

Although, P. persimilis shows oversensitivity for T. urticae against bifenthrin and dimethoate. Toxicity of bifenthrin and dimethoate were harmful effect. Hexythiazox was less toxic than the other pesticides and evaluated as harmless [33], we found almost the same germination rate because of the negatif effects of the beneficial mites. The contact toxicity of Abamectin to beneficials such as, predatory mites Amblyseius fallacis (Garman), Phytoseiulus persimilis and nymphs of Orius insidosus (Say) (Hemiptera: Anthocoridae) was very toxic all the beneficials [34].

Dimethoate was estimated harmful for the predatory mites $P$. persimilis and Neoseiulus californicus, the toxicity on immature Two spotted spider mite was weak [33]. Neem oil reisdues has been evaluated no mortality on P. persimils [35]. [36] reported taht, soil applicationn with neem (Neemm Azal) has strong systemic effects however were recorded in the larval stages of Liriomyza sativae (Diptera: Agromyzidae) attaining mortalities up to $100 \%$. Activity of Neem Azal-U was persistent since application of even seven days before infestation resulted in mortalities extending between $40 \%$ to $70 \%$. This is also effect the helth plants growing. NeemAzal insecticides that have demonstrated high potential control of different harmful pests [11]. Azadirachtin is considered the most important active ingredient contained in neem seeds. This plant extracts shows variable effects on insect pests including oviposition and feeding deterrence, growth regulation, fecundity and fitness reduction [9] [37]. Neem compounds have antiviral [38] antibacterial [39] antifungal [40] antinflammatory effect [41]. It was estimated that all metabolic parameters of exposure diffrent concentration of Nemmazal lepidopter larvae were less than controll larvae. Food intake and faeces output had been decreased due to strong action of Neemazal. The approximated digetsibility values decrease during 4th larval [42].

\section{Conclusion}

All of these have positive effect for the soil fauna and the plant health. Further studies may be required on this subject.

\section{Support}

This study was supported by TÜBİTAK TOVAG 1140416.

\section{References}

[1] Kedici, R., Melan, K. and Kodan, M. (1998) Patates böceği (Leptinotarsa decemlineata Say) nin doğal düşmanlarının tespiti ve Chrysoperla sp. nin zararlının biyolojik mücadelesinde kullanılma imkanlarının araştırılması [Colorado Potato Beetle (Leptinotarsa decemlineata Say) Identification of the Pest's Natural Enemies and Chrysoperla sp. Investigate the Possibility of Using Biological Control]. Bitki Koruma Bülteni. [Plant Protect. Bull.], 38, 13-22.

[2] Öner, S. (2012) Pestisit yanlış kullanımı sonuçları [Improper use of pesticides]. Tarım sağlığı ve güvenliği sempozyumu, Harran Üniversitesi [Agricultural Health and Safety Symposium, Harran University], 6-7 April 2012, Şanliurfa.

[3] Tort, N., Öztürk, İ. and Güvensen, A. (2005) Effects of Some Fungicides on Pollen Morphology and Anatomy of Tomato (Lycopersicon esculentum Mill.). Pakistan Journal of Botany, 37, 23-30.

[4] Ünal, H., Oruç, H., Sezgin, A. and Kabil, E. (2010) Türkiye’de, 2006-2010 yılları arasında, bal arılarında görülen ölümler sonrasında tespit edilen pestisitler [Determined pesticides after honey bee deaths between 2006 and 2010 in Turkey]. Uludă̆ Arıcılık Dergisi [Uludag Bee J.], 10, 119-125.

[5] Önoğur, E. and Çetinkaya, N. (1999) Ekolojik Tarımda Bitki Korumanın Genel İlkeleri [Plant Protection in Ecological 
Agriculture], pp. 111-129. In Ekolojik Tarım Eğitimi Ders Notları [General Principles of Plant Protection in Ecological Agriculture. Ecological Agriculture Education Course Notes], Tarım ve Köyişleri Bakanlığı İzmir İl Müdürlügü̈, E. Ü. Ziraat Fakültesi [Izmir Provincial Directorate of the Ministry of Agriculture and Rural Affairs, E. Ü. Faculty of Agriculture], ETO Derneği Yayınları [ETO Association Publications], Izmir, Turkey.

[6] Tepe, S. (2001) Bitki korumada doğal pestisitlerin kullanimi [The Use of Natural Pesticides for Plant Protection]. Derim, 18, 113-121.

[7] Isman, M.B. (1997) Neem and Other Botanical İnsecticides Banlers to Commercialization. Phytoparasitica, 25, 339344. http://dx.doi.org/10.1007/BF02981099

[8] Ujvary, I. (2001) Pest Control Agents from Natural Products. In: Krieger, R.I., Ed., Hayes’ Handbook of Pesticide Toxicology, Academic Press, San Diego, 109-179. http://dx.doi.org/10.1016/B978-012426260-7.50006-9

[9] Schmutterer, H. (1990) Properties and Potential of Natural Pesticides from the Neem Tree Azadirachta Indica. Annual Review of Entomology, 35, 271-297. http://dx.doi.org/10.1146/annurev.en.35.010190.001415

[10] Koul, O. (2004) Neem-A Global Perspective. In: Koul, O. and Wahab, S., Eds., Neem, Today and in the New Millennium, Kluwer Academic Publishers, The Netherlands, 1-19. http://dx.doi.org/10.1007/1-4020-2596-3_1

[11] Isman, M.B. (2006) Botanical Insecticides, Deterrents and Repellents in Modern Agriculture and an Increasingly Regulated World. Annual Review of Entomology, 51, 45-66. http://dx.doi.org/10.1146/annurev.ento.51.110104.151146

[12] Copping, L.G. and Duke, S.O. (2007) Natural Products That Have Been Used Commercially as Crop Protection Agents. Pest Management Science, 63, 542-554. http://dx.doi.org/10.1002/ps.1378

[13] Kleeberg, H. (2004) Neem Based Products-Registration Requirements, Regulatory Processes and Global Implications. In: Koul, O. and Wahab, S., Eds., Neem, Today and in the New Millennium, Kluwer Academic Publishers, The Netherlands, 109-123. http://dx.doi.org/10.1007/1-4020-2596-3_7

[14] Hoy, M. and Conley, J. (1987) Toxicity of Pesticides to Western Predatory Mite. California Agriculture, 41, 12-14.

[15] FAO (2015) FAOSTAT. Statistics Division, Food and Agriculture Organization (FAO), United Nations. http://faostat3.fao.org/home/E

[16] Kaul, M.K. (1997) Medicinal Plants of Kashmir and Ladakh: Temperate and Cold Arid Himalaya. Indus Publishing Co., New Delhi, 173 p.

[17] Anonymous (2012) Taşköprü sarimsak paneli, bildiri notlan [Taşköprü garlic panel information note]. T.C. Kuzey Anadolu Kalkinma Ajansi, Kastamonu, Türkiye [North Anatolian Development Agency, Kastamonu, Turkey], 132 p. http://www.kuzka.org.tr/paylasim//Sarimsak\%20Kitabi.pdf

[18] Taban, S., Çıkili, Y., Kebeci, F., Taban, N. and Sezer, S.M. (2004) Taşköprü yöresinde sarımsak tarımı yapılan topraklarin verimlilik durumu ve potansiyel beslenme problemlerinin ortaya konulmasi [Fertility status and potential nutritional problems of Taşköprü garlic soils]. Ankara Üniversitesi Ziraat Fakültesi Tarım Bilimleri Dergisi, Ankara [Ankara Univ. Faculty Agric. Sci. J.], 10, 297-304.

[19] Chen, J.S. and Lo, K.C. (1989) Susceptibility of Two Bulb Mites, Rhizoglyphus robini and Rhizoglyphus setosus (Acarina: Acaridae), to Some Acaricides and İnsecticides. Experimental and Applied Acarology, 6, 55-66. http://dx.doi.org/10.1007/BF01193233

[20] Madanlar, N. and Önder, F. (1996) Mites Associated with Cultivated Mushrooms in Turkey. XX International Congress of Entomology, Firenze, 25-31 August 1996, Poster No. 15-138.

[21] Díaz, A., Okabe, K., Eckenrode, C.J., Villani, M.G. and Oconnor, B.M. (2000) Biology, Ecology, and Management of the Bulb Mites of the Genus Rhizoglyphus (Acari: Acaridae). Experimental \& Applied Acarology, 24, 85-113. http://dx.doi.org/10.1023/A:1006304300657

[22] Straub, R.W. (2004) Onion Arthropod Pest Management. http://ipmworld.umn.edu/chapters/straub.htm

[23] Bayram, Ş. and Çobanoğlu, S. (2007) Mite Fauna (Acari: Prostigmata, Mesostigmata, Astigmata) of Coniferous Plants in Turkey. Türkiye Entomoloji Dergisi, 31, 279-290. http://dergipark.ulakbim.gov.tr/entoted/article/viewFile/5000005837/5000006340

[24] Göven, M.A., Çobanoğlu, S. and Güven, B. (2009) Ege Bölgesi bağ alanlarındaki avcı akar faunası (Predator Mite Fauna of the Aegean Coast Vineyards). Bitki Koruma Bülteni (Plant Protection Bulletin), 49, 1-10.

[25] Kılıç, T. (2010) İzmir İlinde Taze Soğanda Bulunan Böcek ve Akar Türlerinin Belirlenmesi, Önemli Olan Zararlı Türün Populasyon Değişiminin İzlenmesi (Fresh Onions in İzmir: Determination of İnsects and Mites Found and Pest Monitoring of Population Changes). Ege Üniversitesi, Fen Bilimleri Enstitüsü (Basılmamış Doktora Tezi) [Ege University, Graduate School of Science and Technology (Unpublished PhD Thesis)], 130 p.

[26] Denizhan, E. (2012) Türkiye eriophyoid faunası için yeni bir kayıt: Aceria tulipae (Keifer, 1938) (Acarina: Eriophyoidea) [A New Record for Turkey Eriophyoid Fauna: Aceria tulipae (Keifer, 1938) (Acari: Eriophyoidea)]. Bitki Koruma Bülteni (Plant Protection Bulletin), 52, 119-122. 
[27] Kılıç, T., Çobanoğlu, S.,Yoldaş Z. and Madanlar, N. (2012) İzmir ilinde taze soğan tarlalarinda bulunan akar (Acari) türleri [Mite (Acari) Species Determined in Fresh Onion Fields in Izmir Province]. Türkiye Entomoloji Dergisi, 36, 401-411.

[28] Başpınar, H., Çakmak, İ. and Öncüer, C. (2000) The Effect of Water Extract of Melia azedarach L. on Some Pests. Proceedings of the Fourth Turkish National Congress of Entomology, Aydın, 12-15 September 2000, 295-304.

[29] Madanlar, N., Yoldaş, Z. and Durmuşoğlu, E. (2000) Laboratory İnvestigations on Some Natural Pesticides for Use against Pests in Vegetable Greenhouses. Integrated Control in Protected Crops, Mediterranean Climate, IOBC wprs Bulletin, 23, 281-288.

[30] Madanlar, N., Yoldaş, Z., Durmuşoğlu, E. and Gül, A. (2002) Izmir'de sebze seralarında zararlılara karşı doğal pestisitlerle savaş olanakları (Investigations on the Natural Pesticides against Pests in Vegetable Greenhouses in IzmirTurkey). Türkiye Entomoloji Dergisi, 26, 181-195.

[31] Koçar, G., Gül, A., Madanlar, N., Yoldaş, Z. and Durmuşoğlu, E. (2003) Effects of Using Natural Pesticides against Pests on Yield and Fruit Quality of Cucumbers Grown under Greenhouse Conditions. Ege Üniversitesi Ziraat Fakültesi Dergisi, 40, 33-40.

[32] Bulut, H.S. and Madanlar, N. (2004) Bazı dogal pestisitlerin laboratuvarda Phytoseiulus persimilis A.-H. (Acarina: Phytoseiidae) e yan etkileri. [Side-Effects of Some Natural Pesticides on the Predatory Mite Phytoseiulus persimilis A.-H. (Acarina: Phytoseiidae) in Laboratory]. Turkiye Entomoloji Dergisi, 28, 115-121.

[33] Alzoubi, S. and Çobanoğlu, S. (2010) Bioassay of Some Pesticides on Two-Spotted Spider Mite Tetranychus urticae Koch and Predatory Mite Phytoseiulus persimilis A-H. International Journal of Acarology, 36, 267-272. http://dx.doi.org/10.1080/01647951003669026

[34] Bostanian, N.J. and Akalach, M. (2006) The Effect of İndoxacarb and Five Other İnsecticides on Phytoseiulus persimilis, Amblyseius fallacis (Acari: Phyytoseiidae) and Nymphs of Orius insidiosus (Hemiptera: Anthocoridae). Pest Management Science, 62, 334-339. http://dx.doi.org/10.1002/ps.1171

[35] Kenneth, W.C., Edwin, E.L. and Peter, B.S. (2002) Compatibility of Acaricide Residues with Phytoseiulus persimilis and Their Effects on Tetranychus urticae. American Society for Horticultural Science ASHS, 37, 906-909.

[36] Hossain, M.B., Poehling, M.H. and Thöming, G. (2008) Effects of Soil Application of Neem (NeemAzal $\left.{ }^{\circledR}-U\right)$ on Different Life Stages of Liriomyza sativae (Diptera: Agromyzidae) on Tomato in the Humid Tropics. Journal of Plant Diseases and Protection, 115, 80-87.

[37] Ruiu, L., Satta, A. and Floris, I. (2008) Effects of an Azadirachtin-Based Formulation on the Non-Target Muscoid Fly Parasitoid Muscidifurax raptor (Hymenoptera: Pteromalidae). Biological Control, 47, 66-70. http://dx.doi.org/10.1016/j.biocontrol.2008.06.013

[38] Gogati, S.S. and Marathe, A.D. (1989) Anti-Viral Effect of Neem Leaf (Azadirachta indica) Extracts on Chinkugunya and Measles Viruses. Journal of Research and Education in Indian Medicine, 8, 1-5.

[39] Singh, N. and Sastry, M.S. (1997) Anti-Microbial Activity of Neem Oil. Indian Journal of Pharmacology, 13, 102106.

[40] Kher, A. and Chauasia, S.C. (1977) Anti-Fungal Activity of Essential Oils of Three Medicinal Plants. Indian Drugs, 15, 41-42.

[41] Morovati, M., Mahmoudi, M., Ghazi-Khansari, M., Aria, A.K. and Jabbari, L. (2008) Sterility and Abortive Effects of the Commercial Neem (Azadirachta indica A. Juss.) Extract NeemAzal-T/S ${ }^{\circledR}$ on Female Rat (Rattus norvegicus). Turkish Journal of Zoology, 32, 155-162.

[42] Mohamed, Z.A., Carmichael, W.W. and Hussein, A.A. (2003) Estimation of Microcystins in the Freshwater Fish Oreochromis niloticus in an Egyptian Fish Farm Containing a Microcystis Bloom. Environmental Toxicology, 18, 137 141. http://dx.doi.org/10.1002/tox.10111 